\title{
Comparative Analysis Of Academic Achievement Index Based On Environmental Health Products In Health Analysis
}

\author{
Aszrul AB ${ }^{1}$, Hariyanti Haris ${ }^{2}$, Sulkifliyawan ${ }^{3}$ \\ Departemen Community and Family Nursing , Stikes Panrita Husada Bulukumba, Indonesia ${ }^{1}$ \\ Departemen Management Nursing , Stikes Panrita Husada Bulukumba, Indonesia ${ }^{2}$ \\ S1 Nursing Study Program, Stikes Panrita Husada Bulukumba, Indonesia ${ }^{3}$
}

Corresponding Autor : aszrulrul@gmail.com

\begin{abstract}
ABSTRAK
Academic achievement is something that cannot be separated from learning activities, because learning activities are a process, while academic achievement is the output of the learning process. In achieving learning achievement, there are several factors, one of which is the person's environment, the environment is one of the factors that influence the formation and development of individual behavior, both the physical and psychological environment, including learning. The purpose of this study was to determine the Analyst Changes in the Academic Achievement Index Based on the Environment in the Health Analyst DIII Study Program at STIKES Panrita Husada Bulukumba in 2018. This type of research is descriptive with a comparative study approach. This study uses a total sampling technique with an observation sheet research instrument. The results of this study indicate that Most of the residence of DIII study program students Health analysts live more with parents than living in the dormitory, the level of achievement of DIII study program students Health analyst every year has decreased this caused by several factors, be it interests, motivations, and the place of the residence itself. Based on changes in academic achievement in semester 1 the number of respondents based on the Predicate in Health Analyst DIII Study Program found the number of respondents in Semester 1. Predicate Compliment as many as 21 respondents (27.6\%), Very Satisfactory Predicate of 37 respondents (48.7\%), Predicate of Satisfaction of 16 respondents $(21.1 \%)$, Predicate of Unsatisfaction of 2 respondents (2.6\%) In semester 2, the number of respondents based on the Predicate in Health Analyst DIII Study Program found the number of predicate respondents in Semester 2. The predicate of praise was 12 respondents (15.8\%), Very Satisfactory Predicate of 25 respondents (32.9\%), Predicate of Satisfaction of 24 respondents (31.6\%), Predicate of Not Satisfactory 15 respondents (19.7\%).
\end{abstract}

Key Word: Change in academic achievement, Environment

\section{INTRODUCTION}

Education is a conscious and planned effort to create an atmosphere of learning and learning process for students to actively develop their potential to have spiritual spiritual strength, self-control, personality, intelligence, noble character, and the skills needed by themselves and the community. Education can be interpreted as a conscious and systematic effort to achieve a standard of living or for better progress (Kadir, 2015). In Indonesia, which regulates the issue of education is the Law on the National 
Education System (UU SIKDIKNAS) Number 20 of 2003. Chapter 2 Article 7 regulates the basis, function and purpose of education.

One indicator of the success of the education process is shown by the learning achievement of students. Academic achievement is something that cannot be separated from learning activities, because learning activities are a process, while academic achievement is the output of the learning process. According poerwodarminto (1995) in Puspitasari W, 2011. achievement is the result that has been achieved, carried out or done by someone, while learning achievement is the achievement achieved, a student at a certain time period. According to (OECD, 2015) Indonesia's educational achievement index in 2015 declined. This decrease was revealed in the report on the ranking results and the value of the Program for International Student Assessment (PISA) in Indonesia. 2015 ranked 64th.

While the level of achievement in one of the largest campuses in South Sulawesi, namely UNM, did a Droup Out (DO) or issued as many as 2,434 students as of January 2018 which was mainly due to academic reasons. Among DO students do not reach the minimum academic standards that have been decided, namely those who do not reach the cumulative achievement index (GPA) of 2.00 and the minimum standard for Semester Credit Units (SKS) based on evaluation results (Republika, 2018). Student achievement varies from one person to another. According to (Ermi, 2017) learning achievement produced by a person is different in relation to the objectives to be achieved. In achieving learning achievement, there are several factors, one of which is the person's environment (Sri, 2012). The environment is one of the factors that influence the formation and development of individual behavior, both the physical environment and the psychological environment, including learning. In the sense that the place where students live themselves each student has a different place of residence, among others, dormitories, living with parents, and boarding houses, so that different caregivers and influences will be different. There is a difference in the achievements of a boarding house from living with parents.

According to research (Efendi, 2010) There is an influence of the boarding environment occupied by students on student achievement in the Geography Education Study Program STKIP PGRI. This study also agrees with the research (Mai Kurniasari Ningtias, 2013) that there are differences between students who live in boarding school and those who do not live in boarding school in Gresik 1 High School, but research 
(Rapitos sidiq, 2013) found that there was no relationship between place status stayed with the level of achievement at banda aceh stikes in 2013. This research is the same as research (Hidayat, 2015) where there is an influence on achievement when it can be supported by parents. According to the results of a preliminary study on the STIKES campus Panrita Husada Bulukumba there are 3 study programs including S1 nursing, Midwifery and Health Analyst DIII, seen from the accumulation of the lowest achievement index namely DIII analyst with an average GPA of 3.00 and even some students who get a GPA of 150 and 2. 75 which can be said to be unsatisfactory, while from nursing and midwifery study programs the average achievement index is 3.80 which is arguably satisfying and can be concluded from the 3 study programs in STIKES Panrita Husada Bulukumba the lowest achievement index is DIII health analyst. The impact of this low GPA can affect many problems, one of which is the job application process.

According to the results of interviews of 10 students of D III Health Analyst at Stikes Panrita Husada Bulukumba who were in the same boarding environment and environment with parents, 10 students who were in the boarding environment were an average of 3.00 while 5 students were in the same environment as parents. average achievement index of 2.90, can be said to be still unsatisfactory.

So the authors are interested in doing the researchers "Comparison of Changes in Academic Achievement Index Based on Environment in Health Analyst DIII Study Program at Panrita Husada Bulukumba 2018"

\section{MATERIAL AND METHODS}

Research Design is a research plan that is arranged in such a way that researchers can get answers to research statements. Research design refers to the type or type of research chosen to achieve research objectives, and to fight as a tool and guide to achieve these goals (Setiadi, 2013). This study uses descriptive research with a comparative study approach because this research causes or risks and consequences or cases that occur in the research object are measured and collected simultaneously or at the same time (Setiadi, 2013).

What was assessed was a Comparison of Changes in Academic Achievement Based on the Kos-Kosan Living Environment and the Living Environment with Their Kandun Parents at Panrita Huadda Bulukumba Stikes Research sites, This research was conducted at the Stikes Panrita Husada Bulukumba campus. Population is a 
generalization area consisting of objects / subjects that have certain quantities and characteristics determined by researchers to be studied and then drawn conclusions (Sugiyono, 2012). The population in this study were all DIII level 2 health analyst students, as many as 76 DIII health analyst students at Stikes Panrita Husada Bulukumba. The sampling technique in this study is stratified random sampling wherein the sample is part of the number of characteristics possessed by the population (Sugiyono, 2012). Meanwhile, according to Syamsuddin, the sample is part of the population.

The sampling technique in this study, namely the total sampling technique with the sample selection method is done by taking all the populations that are used as respondents (Sugiyono, 2012). The number of samples was 76 students. The sampling technique is a sampling technique. To determine the sample used in research, there are various sampling techniques that are used (Sugiyono, 2012). As for the sampling technique in this study, namely the total sampling technique with the sample selection method which is done by taking all the populations that are used as respondents (Sugiyono, 2012). The research instrument is a tool used by researchers to observe, measure or assess a phenomenon. Data obtained from a measurement are then analyzed and made as evidence (evidence) from a study. So the instrument or measuring instrument is an important part in a study (Dharma, 2013). This research instrument to determine academic achievement in the form of observation sheets, observation sheets used are to determine changes in the academic achievement index in the boarding-environment and in the environment with their biological parents. Univariate analysis is performed to describe the frequency distribution of independent and dependent variables

\section{RESULTS}

Table 1. Distribution of Number of Respondents in Study Program DIII Health Analyst

\begin{tabular}{|c|c|c|}
\hline Living environment & Frequency & Percentage (\%) \\
\hline Stay parents & 47 & 61,8 \\
Kos Kosan & 29 & 38,2 \\
\hline Amount & 76 & 100,0 \\
\hline
\end{tabular}

Based on Table 1 shows that the most respondents were in the age group $<30$ namely 69 respondents with a percentage (79.3\%) and 18 respondents (20.7\%) aged $\geq 30$ years. Respondents were female, that is 72 nurses with a percentage of $82.8 \%$ and the rest were male as many as 15 nurses with a percentage of $17.2 \%$. Respondents based on their educational 
background, most of them had DIII Nursing education with 48 nurses with a percentage of $55.2 \%$ and S1 Nursing Nursing with 39 nurses with a percentage of $44.8 \%$. Respondents with years of work $<5$ years 60 respondents with a percentage $(69.0 \%)$ and 27 respondents $(31.0 \%)$ who worked $\geq 5$ years while based on employment status 67 respondents with honorary status with a percentage of $77.0 \%$ and 20 respondents with the percentage of $23.0 \%$ are civil servants.

Table 2. Distribution Of Number Of Respondents Based On The Predicate In The Health Analyst DIII Study Program

\begin{tabular}{cccccccc}
\hline \multirow{2}{*}{ Predicate } & \multicolumn{2}{c}{ Semester 1 } & \multicolumn{2}{c}{ Semester 2 } & \multicolumn{2}{c}{ Semester 3 } \\
\cline { 2 - 7 } & & $\mathrm{F}$ & $\%$ & $\mathrm{~F}$ & $\%$ & $\mathrm{~F}$ & $\%$ \\
\cline { 2 - 7 } & Praise & 21 & 27.6 & 12 & 15.8 & 13 & 17.1 \\
very satisfy & 37 & 48.7 & 25 & 32.9 & 31 & 40.8 \\
Satisfying & 16 & 21.1 & 24 & 31.6 & 20 & 26.3 \\
& 2 & 2.6 & 15 & 19.7 & 12 & 15.8 \\
Not Pass & $\mathbf{7 6}$ & $\mathbf{1 0 0 . 0}$ & $\mathbf{7 6}$ & $\mathbf{1 0 0 . 0}$ & $\mathbf{7 6}$ & $\mathbf{1 0 0 . 0}$ \\
\hline
\end{tabular}

Based on changes in academic achievement in semester 1, the number of respondents based on the Predicate in Health Analyst DIII Study Program found that the number of respondents in Semester 1. Compliment Predicate was 21 respondents (27.6\%), Very Satisfactory Predicate was 37 respondents (48.7\%), Predicate satisfying 16 respondents (21.1\%), predicate less satisfying 2 respondents (2.6\%). In the semester the number of respondents was obtained based on the Predicate in Health Analyst DIII Study Program found the number of respondents predicate in Semester 2. The predicate of praise was 12 respondents (15.8\%), the predicate was very satisfying as many as 25 respondents (32.9\%), the title of satisfying 24 respondents (31.6\%), Unsatisfactory Predicate of 15 respondents (19.7\%).

In semester 3 the number of respondents was obtained based on the predicate in Health Analyst DIII Study Program found the number of respondents in semester 3. Predicate Compliment was 13 respondents (17.1\%), Very Satisfactory Predicate of 32 respondents (40.8\%), Predicate Satisfied 20 respondents (26.3\%), Unsatisfactory Predicate of 12 respondents (15.8\%). On the distribution of respondents based on the environment of residence in the DIII Health Analyst Study Program at Panikes Panrita Husada Bulukumba. The number obtained by the number of respondents in the Neighborhood is 76 respondents, there are 47 respondents (61.8\%) of their biological parents and only 29 respondents (38.2\%) of the Boarding House. 
Table 3. Distribution of the number of respondents according to the Tenpat Environment, Comparison of Academic Achievement, Predicate and semester 1,2,3 In DIII Health Analyst Study Program

\begin{tabular}{|c|c|c|c|c|}
\hline \multirow{2}{*}{ Semester } & \multirow{2}{*}{ Predicate } & \multicolumn{2}{|c|}{ Residence } & \multirow{2}{*}{ Amount } \\
\hline & & Stay parents & Kos-Kosan & \\
\hline \multirow{5}{*}{ Semester_1 } & Praise & 14 & 7 & 21 \\
\hline & Very satisfy & 22 & 15 & 37 \\
\hline & Satisfying & 10 & 6 & 16 \\
\hline & Less satisfactory & 1 & 1 & 2 \\
\hline & Praise & 8 & 4 & 12 \\
\hline \multirow{3}{*}{ Semester_3 } & Very satisfy & 14 & 11 & 25 \\
\hline & Satisfying & 14 & 10 & 24 \\
\hline & Less satisfactory & 11 & 4 & 15 \\
\hline \multirow{5}{*}{ Semester_3 } & Praise & 8 & 5 & 13 \\
\hline & Very satisfy & 14 & 17 & 31 \\
\hline & Satisfying & 17 & 3 & 20 \\
\hline & Less satisfactory & 8 & 4 & 12 \\
\hline & Amount & 47 & 29 & 76 \\
\hline
\end{tabular}

According to the table above distribution in semester 1 the number of respondents was 76 respondents, in the neighborhood of living with their parents as many as 47 respondents with a predicate of 14 respondents, the predicate was very satisfying 22 respondents, the predicate satisfies 10 respondents, the predicate is less satisfying 1 respondent. While in the boarding house environment as many as 29 respondents with a predicate of 7 respondents, the predicate is very satisfying 15 respondents, the predicate satisfies 6 respondents, the predicate is less satisfying 1 respondent. Distribution of the number of respondents living in the neighborhood with their biological parents and the boarding house environment with a predicate of 21 respondents, the predicate is very satisfying 37 respondents, the predicate satisfies 16 respondents, the predicate is less satisfying 2 respondents.

In semester 2 the number of respondents was 76 respondents, in the neighborhood of living with their parents as many as 47 respondents with a predicate of 8 respondents, the predicate was very satisfying 14 respondents, the predicate was satisfying 14 respondents, the predicate was less satisfying 11 respondents. While in the boarding house environment as many as 29 respondents with a predicate of 4 respondents, the predicate is very satisfying 11 respondents, the predicate satisfies 10 respondents, the predicate is less satisfying 4 respondents. Distribution of the number of respondents living in the neighborhood with their biological parents and the boarding house environment with a predicate of 12 respondents, the predicate is very 
satisfying 25 respondents, the predicate satisfies 24 respondents, the predicate is less satisfying 15 respondents.

In semester 3 the number of respondents was 76 respondents, in the neighborhood with Candidate's parents as many as 47 respondents with honors 8 respondents, the predicate was very satisfying 14 respondents, the predicate satisfies 17 respondents, the predicate was less satisfying 8 respondents. While in the boarding house environment as many as 29 respondents with a predicate of 5 respondents, the predicate is very satisfying 17 respondents, the predicate satisfies 3 respondents, the predicate is less satisfying 4 respondents,

Distribution of the number of respondents living in the environment with their biological parents and the boarding house environment with a predicate of 13 respondents, the predicate is very satisfying 31 respondents, the predicate satisfies 20 respondents, the predicate is less satisfying 12 respondents.

\section{DISCUSSION}

Based on research results obtained by researchers the number of respondents based on the Predicate in Health Analyst DIII Study Program found the number of respondents predicate in Semester 1. Predicate Compliment of 21 respondents (27.6\%), Very Satisfactory Predicate of 37 respondents (48.7\%), Predicate Satisfying 16 respondents (21.1\%), Predicate Less Satisfactory 2 respondents (2.6\%). While the number of respondents based on the Predicate in Health Analyst DIII Study Program found the number of respondents predicate in Semester 2. Compliment predicate as many as 12 respondents (15.8\%), Very Satisfactory Predicate of 25 respondents (32.9\%), Predicate Satisfying 24 respondents (31,6\%), Predicate Less Satisfying 15 respondents (19.7\%). And the number of respondents based on the predicate in Health Analyst DIII Study Program found the number of predicate respondents in semester 3 of the Compliment Predicate was 13 respondents (17.1\%), Very Satisfactory Predicate of 32 respondents (40.8\%), the Predicate Satisfied 20 respondents (26.3\%), The predicate is less satisfying for 12 respondents (15.8\%).

Academic achievement is the result of lessons obtained from learning activities in schools or colleges that are cognitive and are usually determined through measurement and assessment. Academic achievement in this study was assessed based on GPA (Grade Point Average). Achievement Index (IP) is an assessment of the success of semester studies conducted at the end of each semester. (Safitri Daruyani1, 2013). 


\section{COMPRABANSIVEAEAH CARE}

This research is in line with previous research conducted by Rapitos, which every year has decreased the level of student achievement where the results in semester 1 found that most of the results of semester 1 student learning achievement with a very satisfactory achievement index of 53 people or $47.32 \%$. Whereas in semester 2 it was found that most of the results of the second-level student learning achievement with the achievement index (IP) of the category were very satisfying, namely 62 people or $53.45 \%$. And in the third semester it was found that most of the results of third-grade student achievement with the category of achievement index (IP) were very satisfying, namely 57 people or $50.44 \%$. So the researchers assume that the decline in IPK every year is due to the difficulty of the learning system every semester improvement and the more difficult division of time for each lecturer's assignments because each lecturer gives assignments and is collected as soon as possible even though the material is difficult to obtain good material in the library and internet why is it difficult to be found because of the material we provide must be the same as the opinion of the lecturer, there are several lecturers who explain the meter difficult to understand for every student. So that students are overwhelmed to master the material not to mention, so that students' interest and motivation to learn decreases because that is what usually causes lazy learning and indifferent to the material given by the lecturer. This causes more students to not understand the material, the final time and practical test students answer their aladadar so that students experience a decrease every semester.

Based on the results of the distribution of the number of respondents in the Neighborhood there were 76 respondents, there were 47 respondents (61.8\%) of their biological parents and only 29 respondents (38.2\%) living. The environment is a combination of physical conditions that cover the state of natural resources such as land, water, solar energy, minerals, and flora and fauna that grow on land or in the ocean, with institutions that include human creation such as decisions on how to use the physical environment, (Rahman, 2011). This study is not in line with the study, (Indriyani, 2014), with the title of school and residence influences on student achievement, which says that most of the students' residences (61.7\%) live in boarding houses compared to living with their biological parents .

However, this study agrees with the research, (Rapitos Sidiq, 2013) with the title relationship of residence status with student learning achievement in the banda Aceh Nursing Study Program, which says that most of the Banda Aceh Nursing Study Program 
students with the status of residence with parents, namely 207 people from 340 people who were respondents in this study. This means that $60.88 \%$ of students live with parents, Research (Iffah, 2017) agrees with this study with the title difference in motivation and learning achievement between commanding students and boarding students in social studies students of the Faculty of Social Sciences Tarbiya and Teacher Training UIN Hidayatullah Jakarta who said that those who said the commander students (72.27) were higher compared to the average boarding student (72.46) from each of the 26 respondents.

So the researchers assume that the residence is very important to be monitored to get maximum results on student achievement, where with early monitoring can immediately provide action to improve everything that deviates from the rules and discipline of students. The environment is influential with interest and motivation to learn because students who live with their biological parents have higher interest and motivation to learn which are being assisted by their parents, which causes most students to prefer to live in their parents' parents and students are not too burdened with their finances. because every day is given enough pocket money to cover their needs compared to students who live in boarding houses which are divided in their thoughts about boarding fees and food costs so that students find it difficult to concentrate on studying, students who live in the environment of orangutans feel safe and students who live in the environment of parents the biological is more comfortable to study because it is supported by her parents. This is what causes students to prefer the environment to live in their biological parents.

\section{CONCLUSIONS}

The level of achievement of DIII study program students Health analysts decline every year due to several factors, be it interests, motivations, and the place of residence itself. It is recommended to other researchers to analyze other factors that lead to differences in learning achievement in the lives of DIII study program Health Analysts

\section{REFERENCES}

Ayu Desi Indrawati, D. K. (2011). Fakultas Ekonomi dan Bisnis Universitas Udayana. Analisis Faktor Penentu Prestasi Belajar Mahasiswa Fakultas Ekonomi Dan Bisnis Universitas Udyana.

Budianto, A. (2013). Diajukan Kepada Fakultas Ekonomi Universitas Negeri Yogyakarta untuk Memenuhi Sebagian Persyaratan. Pengaruh Motivasi Belajar Intrinsik Dan Minat 
Belajar Terhadap Prestasi Belajar Mahasiswa Pendidikan Administrasi Perkantoran Angkatan 2010 Fakultas.

Didik Kurniawan, D. U. (2014). Pengaruh Perhatian Orangtua, Motivasi Belajar, Dan Lingkungan Sosial Terhadap Prestasi Belajar Matematika Siswa Smp .

Dr. Bambang Daru Nugroho, S. M. (2017). Hukum Perdata Indonesia. Bandung: PT Refika Aditama.

Drs. Henry Eryanto, M. D. (2013). Pengaruh Modal Budaya, Tingkat Pendidikan Orang Tua Dan Tingkat Pendapatan Orang Tua Terhadap Prestasi Akademik Pada Mahasiswa Fakultas Ekonomi Universitas Negeri Jakarta.

Hamid, M. H. (2013). Dosen DPK FKIP Universitas Almuslim. Hubungan Antara Motivasi Dengan Prestasi Belajar Ekonomi Siswa Kelas Viii Smp Negeri 2 Jangka .

Iffah, F. F. (2017). Perbedaan Motivasi Dan Prestasi Belajar Antara Mahasiswa Penglaju Dan Mahasiswa Kos Pada Mahasiswa Pendidikan Ips Ggakkultas IImu Tarbiyah Dan Keguruan Uin Syariff Hidayatullah Jakarta .

Indriyani, R. (2014). Pengasuh Asal Sekolah Dan Tempat Tinggal Terhadap Prestasi Belajar Mahasiswa .

Kartika, K. (2007). Hubungan Pemenuhan Kebutuhan Berafiliasi Dengan Tingkat Stres Pada Mahasiswa Kos.

Karyanah, Y. (2015). Program studi ilmu Keperawatan Universitas Esa Unggul Jalan Arjuna Utara No. 9 Kebun Jeruk Jakarta 11510 yayah.karyanah@esaunggul.ac.id. Hubungan Asal Jurusan Dengan Prestasi Belajar Mahasiswa Program Studi IImu Keperawatan .

Mai Kurniasari Ningtias, M. (2013). Perbedaan Motivasi Belajar Dan Prestasi Belajar Pada Siswa Yang Menggunakan Sistem Boarding School Dan Siswa Yang Tidak Menggunakan Sistem Boarding School Di Sma Muhammadiyah 1 Gresik.

Notoatmodjo, s. (2014). Metode Penelitian Kesehatan. Jakarta: Renika Cipta.

Nur Fitriyani, P. B. (2013). Hubungan Antara Konformitas Dengan Perilaku Konsumtif Pada Mahasiswa Di Genuk Indah Semarang .

Nursalam. (2016). Metodologi penelitian ilmu keperawatan. Jakarta: Salemba Medika.

Pratiwi, S. Y. (2009). Hubungan Antara Tingkat Religiusitas Dan Pengetahuan Seksualitas Dengan Intensitas Masturbasi Pada Mahasiswa Yang Tinggal Di Kos .

Rahman, A. R. (2011). Jurusan Pendidikan Teknik Elektronika, Fakultas Teknik, Universitas Negeri Yogyakarta . Pengaruh Motivasi, Lingkungan Dan Disiplin Terhadap Prestasi Belajar Siswapada Jurusan Teknik Audio Video Smk Negeri 3 Yogyakarta . 


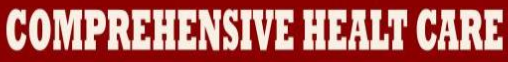

Rapitos sidiq, A. ,. (2013). Hubungan Status Tempat Tinggal Dengan Pretasi Belajar Mahhasiswa/Prodi Keperawatan Banda Aceh Poltekkes.

Rindang Gunawati, S. H. (2006). Studi Psikologi Universitas . Hubungan Antara Efektivitas Komunikasi Mahasiswa dosen Pembimbing Utama Skripsi Dengan Stres Dalam Menyusun Skripsi Pada Mahasiswa Program Studi Psikologi Fakultas Kedokteran Universitas Diponegoro, 94.

Safitri Daruyani1, Y. W. (2013). Faktor-faktor Yang Mempengaruhi Indeks Prestasi Mahasiswa Fsm Universitas Diponegoro Semaster Pertama Dengan Motode Regresi Logistik Biner.

Saleh, M. (2014). Pengaruh Motivasi, Faktor Keluarga, Lingkungan Kampus Dan Aktif Berorganisasi Terhadap Prestasi Akademik.

Saryono. (2010). Yogyakarta.

Setiadi. (2013). Konsep Dan Pratik Penulisan Riset Keperawatan. Yogyakarta: Graha Ilmu.

Singgih Tego Saputro, P. (2012). Jurnal Pendidikan Akuntansi Indonesia,. Pengaruh Disipin Belajar dan lingkungan terhadap prestasi belajar Mahasiswa Program Studi Pedidikan Akutansi Ankata 2009 Fakultas Ekonomi Universitas Negeri Yogyakarta, 82.

Sugiyono. (2012). Metodologi Penelitain Kuantitatif,kallitatif,dan R dan D. Bandung: Alfabeta CV.

Suprapti, D. A. (2014). Hubungan antara Self Efficacy dengan Subjective Well-Being pada Mahasiswa Baru Politeknik Elektronika Negeri Surabaya (PENS) yang Kos.

Wastika, D. N. (2005). Penerapan Konsep Tri Hita Karana Dalam Perencanaan Perumahan Di Bali. 